\title{
The impact of environmental air pollution on the prevalence of molar incisor hypomineralization in schoolchildren: A cross-sectional study
}

\author{
Natalia Gtódkowska ${ }^{A-D, F}$, Katarzyna Emerich ${ }^{A, E, F}$ \\ Department of Pediatric Dentistry, Medical University of Gdańsk, Poland \\ A - research concept and design; $\mathrm{B}$ - collection and/or assembly of data; $\mathrm{C}$ - data analysis and interpretation; \\ $D$ - writing the article; $E$ - critical revision of the article; $F$ - final approval of the article
}

Address for correspondence

Katarzyna Emerich

E-mail: emerich@gumed.edu.pl

\section{Funding sources}

This work was supported by funds from the Polish Ministry of Science and Higher Education, granted to maintain statutory activities.

Conflict of interest

None declared

\section{Acknowledgements}

The authors wish to thank Dr. Jan Kaczmarek for his enthusiastic and tireless help and his encouragement during the preparation of the manuscript.

Received on April 15, 2020 Reviewed on May 20, 2020 Accepted on 0ctober 8, 2020

\section{Cite as}

Głódkowska N, Emerich K. The impact of environmental air pollution on the prevalence of molar incisor hypomineralization in schoolchildren: A cross-sectional study. Adv Clin Exp Med. 2020;29(12):1469-1477.

doi:10.17219/acem/128227

DOI

10.17219/acem/128227

\section{Copyright}

Copyright by Author(s)

This is an article distributed under the terms of the

Creative Commons Attribution 3.0 Unported (CC BY 3.0)

(https://creativecommons.org/licenses/by/3.0/)

\begin{abstract}
Background. Molar incisor hypomineralization (MIH) is a common condition that causes considerable pain to children and distress to their parents. Clinically it is manifested by demarcated opacities of tooth enamel with reduced mineralization. The mean global incidence of this disorder has been estimated at around 13-14\%. Environmental pollution is one of the suspected etiological factors, but the impact of air pollutant components on MIH has yet to be studied.

Objectives. To assess whether the level of air pollution components has an impact on the prevalence of $\mathrm{MIH}$.

Material and methods. This cross-sectional study included 2354 children, aged 6-12 years, attending schools in 2 voivodeships (regions) of Poland with best and worst air quality. Smog alarms are announced more than 50 times a year in the Silesian voivodeship, while in the Pomeranian voivodeship, consistently low levels of air pollution are observed. Our air quality assessment was carried out on the basis of average annual results from measuring stations located in the 2 voivodeships. Dental examinations of teeth were conducted using the European Academy of Paediatric Dentistry (EAPD) criteria for the diagnosis of MIH.

Results. Levels of air pollution components over time were notably higher in the Silesian voivodeship, especially sulfur dioxide $\left(\mathrm{SO}_{2}\right)$, particulate matter (PM10) and polycyclic aromatic hydrocarbons (PAH). The MIH was diagnosed more often in children in the Silesian voivodeship (13.7\%) than in the Pomeranian (6.4\%). In the Pomeranian voivodeship, MIH was most often diagnosed in children aged 6 (14.53\%).

Conclusions. This study shows a correlation between higher concentrations of air pollutants and the $0 C_{-}$ currence of enamel developmental disorder in the form of $\mathrm{MIH}$. Future research is required to assess whether this is related to the presence of a specific component or to the more frequent occurrence and treatment of air pollution-related general diseases, such as respiratory illnesses.
\end{abstract}

Key words: children, air pollution, prevalence, enamel defects, molar incisor hypomineralization 


\section{Introduction}

Due to increasing awareness as well as a decline in the incidence of dental caries, researchers have been focusing on developmental disorders of the teeth. One developmental disorder of enamel, first described in 2001, is molar incisor hypomineralization $(\mathrm{MIH}) .{ }^{1}$ It involves reduced mineralization and increased porosity of the tooth enamel, and involves the first permanent molars (FPM) and often the permanent incisors (PI). ${ }^{1}$ Clinically the changes are manifested as white, cream-yellow or brown opacities, clearly demarcated from healthy enamel (Fig. 1). The affected enamel has a disturbed structure and, due to the effects of chewing forces, it may break down soon

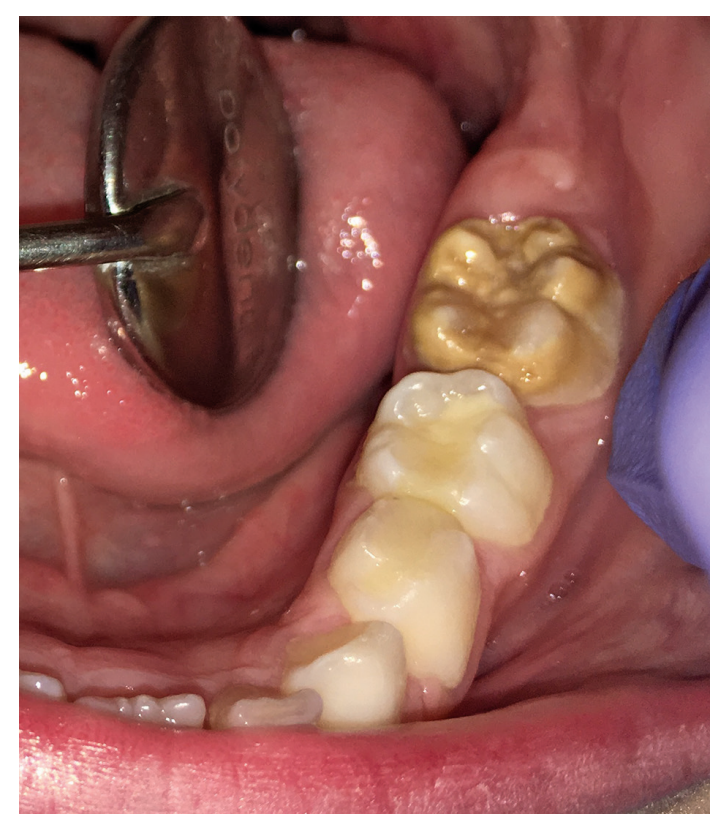

Fig. 1. Demarcated opacities on first permanent molar

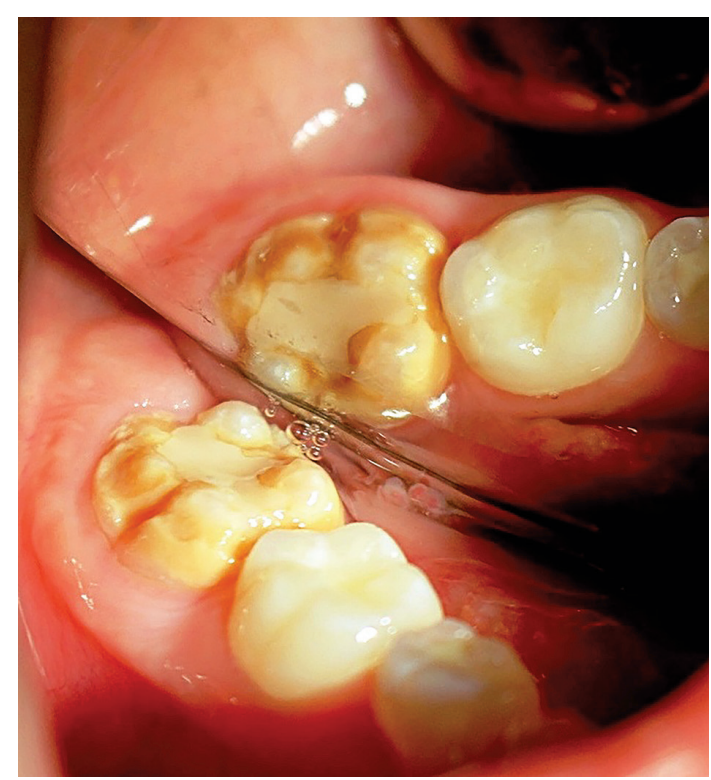

Fig. 2. Posteruptive breakdown (PEB) of first permanent molar

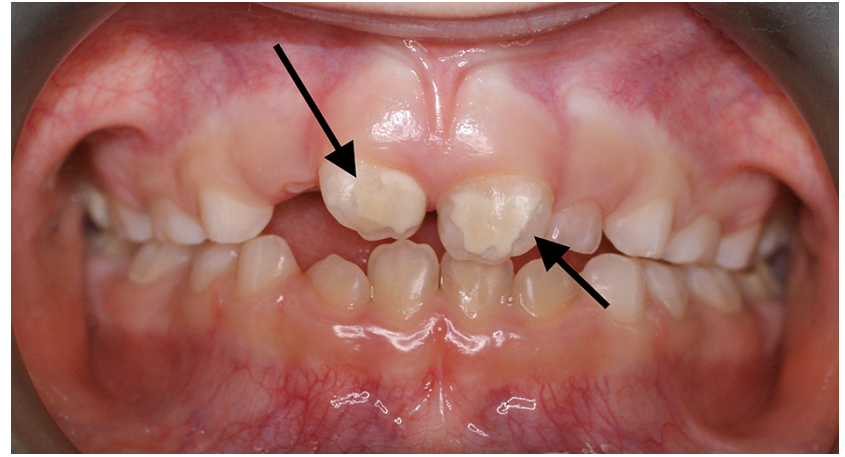

Fig. 3. Demarcated opacities on permanent incisors

after eruption, resulting in a significant loss of mineralized tooth structure (Fig. 2). ${ }^{2}$

The MIH is a public health problem whose consequences are not only health-related but also economic. For the patient, these teeth are the cause of discomfort and sometimes pain (even during brushing), and often require advanced treatment at a very young age. Furthermore, when the disorder also includes incisors - visible when smiling - it can create a major esthetic problem (Fig. 3). Visible patches can negatively affect the patient's well-being and their contact with peers. ${ }^{3}$

For a dentist, treating children with MIH represents a significant challenge. ${ }^{4}$ The affected teeth cause pain and hypersensitivity, and often do not undergo sufficient anesthesia, compromising the child's cooperation. Children with MIH are more prone to suffer from dental phobia than healthy ones. Furthermore, the incorrect enamel structure does not allow for the effective adhesion of materials, and fillings often chip off, necessitating repeated treatment. Studies show that children with MIH require more frequent treatment than children without MIH. ${ }^{5}$ Treatment mainly concentrates on prevention of post-eruptive enamel fractures and reduction of tooth sensitivity. However, in more advanced cases - where there is a loss of hard tooth tissues - tooth reconstruction is required; sometimes it is even necessary to extract teeth at a very young age. The MIH is considered to be the second biggest cause of permanent molar loss after caries, emphasizing the need for deeper understanding of this disorder and the possibility of its prevention. ${ }^{6}$

In the last few years, several papers have been published on the prevalence of $\mathrm{MIH}{ }^{7}$ In 2 recent meta-analyses, the average prevalence was estimated at $14.2 \%$ and $13.1 \%$ (range: $2-40 \%$ ), with statistically significant differences between macroregions, regions and countries. ${ }^{8-10}$ These studies confirm that the number of $\mathrm{MIH}$ cases is still growing, with the highest prevalence being in high-income countries. ${ }^{9}$

Despite many attempts to establish the etiology of this disorder, no single specific factor responsible for the occurrence of MIH has been identified. Determining a specific etiological factor is difficult because the research conducted is often retrospective. First permanent molar 
disorders can be diagnosed only following their eruption, i.e., around 6-7 years of age, while the amelogenesis of these teeth occurs much earlier, i.e., in the perinatal period and the first years of a child's life, so the causative factor must work at that time. Parents often do not remember the history of illnesses and the medicines taken a few years ago. ${ }^{10}$ In the literature, the following suspected factors are presented, among the others: childhood illness, prematurity, fevers, otitis media, hypoxia at birth, pneumonia, and drugs taken, including antibiotics. ${ }^{11-15}$ Scientists are also trying to find a genetic predisposition for this disorder, but there is still no clear evidence of one. ${ }^{15,16}$ At present, the etiology is considered multifactorial, without indicating any single specific causal factor. ${ }^{17}$

Researchers' hypotheses also increasingly point to environmental pollution as a predisposing factor for MIH. Due to the toxic effects on human health even many years after exposure, dioxins have been considered a predisposing factor for dental development disorders. They belong to the group of persistent organic pollutants (POPs) that are still a considerable component of environmental pollution. ${ }^{18}$ Studies have shown a correlation between exposure to dioxins (mainly due to their excretion in breast milk), prolonged breastfeeding and the occurrence of $\mathrm{MIH},{ }^{19}$ although other researchers have rejected this hypothesis. ${ }^{20}$ In the literature, one can also find a link between exposure to polychlorinated biphenyls (PCBs) and their impact on enamel development, including hypomineralization. ${ }^{21}$ Other contaminants, such as polycyclic aromatic hydrocarbons and respirable particulate matter with a diameter of up to $10 \mu \mathrm{m}$ (PM10), also pose a threat to human health.

There is still little evidence that can unequivocally confirm or rule out a link between environmental pollution and the occurrence of MIH. To our knowledge, the relationship between $\mathrm{MIH}$ and the level of common air pollutant components other than PCBs has yet to be studied. The aim of this study is thus to determine the prevalence of MIH in 2 different regions of Poland - the Pomeranian and Silesian voivodeships - which, due to their location and industrialization, differ substantially in the intensity of air pollutants. Based on previous research, it can be hypothesized that air quality influences the prevalence of MIH.

\section{Methods}

\section{Study design and sampling procedures}

The study was conducted in primary schools in 2 voivodeships in Poland: Pomeranian and Silesian. The research group was made up of children residing in the Silesian voivodeship, while children from Pomeranian voivodeship were assigned to the negative control group. There are 719 primary schools in the Pomeranian voivodeship and 1454 in the Silesian. Special care schools, penal institutions, correctional schools, and schools in hospitals were excluded, leaving 553 schools in the Pomeranian voivodeship and 1324 in the Silesian voivodeship qualified for the study. According to the latest data, 150,372 children aged 6-12 attend primary schools in the Pomeranian voivodeship and 260,789 in the Silesian voivodeship, so assuming a 95\% confidence level, 383 children in Pomerania and 384 in Silesia should be examined for the group to be representative. According to recommendations from Elfrink et al., 7 for assessing the prevalence of MIH estimated at 5\%, a minimum group of 300 children is required, and a minimum number of 1000 children is recommended to evaluate a possible MIH etiological factor.

We selected 30 schools from the Pomeranian voivodeship and 15 from the Silesian voivodeship, and sent letters to the school heads inviting them to participate in the study.

\section{Ethical considerations}

The Independent Bioethics Committee for Scientific Research at the Medical University of Gdańsk gave their approval (No. NKBBN/182/2013) to conduct the study. Permission was obtained to conduct the study in 15 schools in the Pomeranian voivodeship and 7 in the Silesian. Information regarding the study and consent forms for participation in the study was sent to the parents or legal guardians of children aged 6-12. On the day of the study, children without a parent's or guardian's permission, children with general medical diseases, and children who were uncooperative or did not assent to the examination were excluded from the study.

\section{Study location and air pollution measurement methods}

The Pomeranian voivodeship is located in the north of the country, on the Baltic Sea coast, while Silesia is located in the south of the country, about $600 \mathrm{~km}$ away. Smog alarms are announced more than 50 times a year in the Silesian voivodeship; in the Pomeranian voivodeship, constantly low levels of air pollution are observed. In both voivodeships, stations measuring the level of air pollution are located in various cities. The number of stations has changed over time; there are currently 20 in the Pomeranian voivodeship and 30 in Silesian. The stations perform hourly or 24-hour tests. The archived results are posted on the website of the Chief Inspectorate for Environmental Protection in Poland at http://powietrze.gios.gov.pl/pjp/current.

The enamel mineralization of FPM and PI starts in the perinatal period and ends at the age of about 3 years. Given that the study was conducted in the years 2016-2019, studied children aged 6-12 were born between 2004 and 2012. Therefore, the air pollution levels from 2004 to 2013 were taken into account for the study. In order to assess air quality in those years, archive data on the level of pollution 
were averaged for each year. The available measurements for air pollutant components comprise:

- inorganic gas pollutants: sulfur dioxide $\left(\mathrm{SO}_{2}\right)$, nitrogen dioxide $\left(\mathrm{NO}_{2}\right)$, nitrogen oxides $(\mathrm{NOx})$, ozone $\left(\mathrm{O}_{3}\right)$, and carbon monoxide $(\mathrm{CO})$;

- particulate matter (PM10);

- heavy metals in PM10: lead (Pb; PM10), arsenic (As; PM10), cadmium (Cd; PM10) and nickel (Ni; PM10);

- volatile organic compounds: benzene $\left(\mathrm{C}_{6} \mathrm{H}_{6}\right)$;

- polycyclic aromatic hydrocarbons (PAHs) in PM10: benzo(a)pyrene (BaP; PM10), benzo(a)anthracene (BaA; PM10), benzo(b)fluorantene (BpF;PM10), benzo(k)fluorantene (BkF; PM10), and benzo(j)fluroantene (BjF; PM10).

\section{Study settings}

Each child's dental examination was carried out at school using a dental probe, an oral mirror and a head lamp. The teeth were not cleaned or dried before examination. When necessary, cotton rolls were used to remove food debris. All the surfaces of the index teeth were examined, and $\mathrm{MIH}$ was diagnosed according to the criteria published by Weerheijm et al. ${ }^{22}$ (Table 1 ). Only defects greater than $1 \mathrm{~mm}$ in diameter were reported. All the examinations of all the children were performed by the same investigator (NG), who was trained and calibrated before the process commenced. The reliability of that examiner was also assessed by re-examination of every $10^{\text {th }}$ child.

\section{Statistical analyses}

Descriptive statistics of the data were generated using standard statistical parameters: percentage, mean (M) and standard deviation (SD), median, and minimum and maximum (min and max). Correlations between pairs of numerical parameters were studied using the $X^{2}$ test. The air quality was compared using Student's t-test for independent samples. A p-value $<0.05$ was considered statistically significant for all tests. The data were organized into files (Microsoft Excel 2013; Microsoft Inc., Redmond, USA) and statistically processed using STATISTICA v. 13.1 software (StatSoft Inc., Tulsa, USA).

\section{Results}

\section{Characteristics of the surveyed population}

The study involved 2354 children (a response rate of $67.3 \%)$ aged $6-12(\mathrm{M}=8.80, \mathrm{SD}=1.89)$, of whom $50 \%$ were girls and $50 \%$ were boys. Most of the children (61\%) came from the Pomeranian voivodeship, while over a third (39\%) were from the Silesian voivodeship. Over 75\% lived in cities, while $23 \%$ lived in rural areas. We excluded 79 children from the study because they had no erupted permanent molars. A total of $96.7 \%(n=2275)$ of the examined children had at least 1 erupted FPM and were included in the study, so assuming a 95\% confidence level, the statistical error can be assessed as $2 \%$ for the entire population.

\section{Characteristics of air pollution}

The annual average air pollutants for both voivodeships are presented in Table 2 . The statistical analysis of the data showed significantly higher levels of most of the pollutants measured in the Silesian voivodeship than in the Pomeranian. The greatest differences were observed in the cases of $\mathrm{SO}_{2}$ and $\mathrm{PAH}$, especially $\mathrm{BaP}$ (PM10). The concentrations of these substances in the south of Poland were almost 4 times higher than in the north of the country. In terms of PM10, $\mathrm{C}_{6} \mathrm{H}_{6}, \mathrm{NO}_{2}$ and $\mathrm{CO}$ the levels were almost double in Silesian voivodeship than in Pomeranian. In the group of heavy metals in PM10, the mean values of lead, cadmium and arsenic were also significantly higher in the Silesian voivodeship. The level of Ni (PM10) turned out to be higher in the Pomeranian voivodeship, but the difference was not statistically significant. The only statistically significant higher level in the Pomeranian voivodeship was the $\mathrm{O}_{3}$ concentration.

\section{Distribution and dissemination of MIH depending on the voivodeship}

The MIH was diagnosed in 212 children, representing $9.32 \%$ of the study population. The $X^{2}$ analysis revealed statistically significant differences between the prevalence

Table 1. MIH diagnostic criteria according to Weerheijm et al. ${ }^{22}$

\begin{tabular}{|l|l|}
\hline $\begin{array}{l}\text { Demarcated opacity } \\
\text { Post-eruptive enamel } \\
\text { breakdown (PEB) }\end{array}$ & $\begin{array}{l}\text { A demarcated defect involving an alteration in the translucency of the enamel, variable in degree. The defective enamel } \\
\text { is of normal thickness with a smooth surface and can be white, yellow or brown in color. }\end{array}$ \\
\hline Atypical restoration & $\begin{array}{l}\text { A defect that indicates deficiency of the surface after eruption of the tooth. Loss of initially formed surface enamel after } \\
\text { tooth eruption. The loss is often associated with a pre-existing demarcated opacity. } \\
\text { The size and shape of restoration do not conform to the temporary caries picture. In most cases, in molars these are } \\
\text { restorations extended to the buccal or palatal smooth surface. At the border of the restorations frequently opacity can be } \\
\text { noticed. In incisors, a buccal restoration can be noticed not related to a trauma. }\end{array}$ \\
\hline Extracted molar due to MIH & $\begin{array}{l}\text { The absence of a first permanent molar should be assessed in relation to other teeth. Reasons for considering extraction } \\
\text { due to MIH are: Opacities or atypical restorations in the other first permanent molars combined with absence of a first } \\
\text { permanent molar. The absence of first permanent molars in sound dentition in combination with demarcated opacities } \\
\text { on the incisors is likely to be due to MIH. It is not likely that incisors will be extracted due to MIH. } \\
\text { The first permanent molar or the incisor to be examined are not yet erupted. }\end{array}$ \\
\hline
\end{tabular}


Table 2. Annual average air pollutants for both voivodeships

\begin{tabular}{|c|c|c|c|c|c|c|c|c|c|c|c|c|c|c|c|c|c|}
\hline \multirow[t]{2}{*}{ Year } & \multirow{2}{*}{$\begin{array}{l}\text { Voivode- } \\
\text { ship }\end{array}$} & \multicolumn{2}{|c|}{$\begin{array}{c}\mathrm{SO}_{2} \\
{\left[\mu \mathrm{g} / \mathrm{m}^{3}\right]}\end{array}$} & \multicolumn{2}{|c|}{$\begin{array}{c}\mathrm{NO}_{2} \\
{\left[\mu \mathrm{g} / \mathrm{m}^{3}\right]}\end{array}$} & \multicolumn{2}{|c|}{$\begin{array}{c}\mathrm{NOx} \\
{\left[\mu \mathrm{g} / \mathrm{m}^{3}\right]}\end{array}$} & \multicolumn{2}{|c|}{$\begin{array}{c}\mathrm{O}_{3} \\
{\left[\mu \mathrm{g} / \mathrm{m}^{3}\right]}\end{array}$} & \multicolumn{2}{|c|}{$\begin{array}{c}\mathrm{CO} \\
{\left[\mathrm{mg} / \mathrm{m}^{3}\right]}\end{array}$} & \multicolumn{2}{|c|}{$\begin{array}{c}\text { PM10 } \\
{\left[\mu \mathrm{g} / \mathrm{m}^{3}\right]}\end{array}$} & \multicolumn{2}{|c|}{$\begin{array}{c}\mathrm{Pb}(\mathrm{PM} 10) \\
{\left[\mu \mathrm{g} / \mathrm{m}^{3}\right]}\end{array}$} & \multicolumn{2}{|c|}{$\begin{array}{c}\text { As (PM10) } \\
{\left[\mathrm{ng} / \mathrm{m}^{3}\right]}\end{array}$} \\
\hline & & Avg. & SD & Avg. & SD & Avg. & SD & Avg. & SD & Avg. & SD & Avg. & SD & Avg. & SD & Avg. & SD \\
\hline \multirow{2}{*}{2013} & lesian & 3.595 & 15.654 & 4.407 & 7.822 & 2.987 & 9.033 & 48.352 & 31.393 & 0.52 & 0.367 & 4.183 & 31.877 & .039 & 0.035 & 1.719 & .058 \\
\hline & Pomeranian & 5.009 & 573 & 4.581 & 1.766 & 2.229 & 5.469 & 53.094 & 24.611 & 0.394 & .241 & 24.057 & 15.318 & 0.009 & 0.006 & 1.027 & 0.202 \\
\hline \multirow{2}{*}{2012} & Siles & .959 & 15.074 & 21.343 & .161 & 8.806 & 3.254 & 50.644 & 33.394 & 0.632 & 646 & 45.318 & 43.757 & .038 & 0.034 & 1.866 & 1.828 \\
\hline & Pomeran & 5.113 & 9.678 & 611 & 7.763 & 4.351 & 8.666 & 47.903 & 24.183 & 0.377 & .257 & 5.032 & 19.437 & .013 & 0.015 & 1.358 & 1.479 \\
\hline \multirow{2}{*}{2011} & n & 1.052 & 12.61 & 241 & 2.032 & 7.017 & 8 & +8.153 & 31.581 & 0.614 & .584 & 26 & .945 & 036 & .031 & 214 & .326 \\
\hline & Pomeran & 3.838 & 6.795 & 646 & .461 & 8.472 & 1.571 & 49.674 & 25.972 & 0.381 & 0.305 & 256 & 20.758 & 026 & 0.105 & 1.174 & 0.519 \\
\hline \multirow{2}{*}{2010} & - & .087 & 19 & & 3 & 2 & & 266 & 8 & 648 & 19 & 88 & 79 & 0.04 & .047 & 4.845 & 5.341 \\
\hline & Pom & 3.746 & 5.274 & 841 & 378 & .646 & 95 & 51.617 & 24. & 0.429 & 354 & 3.223 & 43 & 0.015 & 0.015 & 1.076 & 0.471 \\
\hline \multirow{2}{*}{2009} & sian & 4.548 & 12.381 & 4.176 & 18.807 & 3.651 & 8.273 & 46.133 & 32.278 & .553 & 483 & 1.974 & 36.845 & 0.037 & 0.033 & 3.348 & 2.329 \\
\hline & Pomeranian & 878 & 4.482 & 18.042 & 15.303 & 27.96 & 5.716 & 47.42 & 26.024 & 0.39 & 0.306 & 25.611 & 19.903 & 0.044 & 0.081 & 2.927 & 2.789 \\
\hline \multirow{2}{*}{2008} & Silesian & .421 & 9.186 & 5.002 & 18.696 & 45.282 & 7.854 & 45.0 & 32.375 & 0.561 & 0.456 & 38.43 & 34.091 & $\mathrm{n} / \mathrm{d}$ & $n / d$ & $\mathrm{n} / \mathrm{d}$ & $n / d$ \\
\hline & Pomerar & 3.413 & 4.707 & 17.134 & 13.611 & 3.692 & 7.544 & 53.077 & 19.064 & 0.367 & 0.238 & 2.923 & 16.689 & 0.031 & 0.039 & 1.46 & 1.976 \\
\hline \multirow{2}{*}{2007} & गा stan & 11.444 & 10.769 & 92 & 34 & 19.484 & 62 & 45.196 & 46 & 0.601 & 0.498 & 35.457 & 33.874 & $\mathrm{n} / \mathrm{d}$ & $n / d$ & $\mathrm{n} / \mathrm{d}$ & $n / d$ \\
\hline & POII & 2.105 & & & 604 & 58 & & 55.77 & & 327 & 7 & 84 & & 0.016 & 2 & $n / d$ & $n / d$ \\
\hline \multirow{2}{*}{2006} & & 22.45 & 34 & 31.134 & & 18.339 & 6 & 47.389 & & 0.815 & 0.767 & 48.567 & & $\mathrm{n} / \mathrm{d}$ & $\mathrm{n} / \mathrm{d}$ & $n / d$ & $\mathrm{n} / \mathrm{d}$ \\
\hline & P & .009 & 9 & 7.8 & 9 & 216 & & 58.937 & 2 & 399 & 287 & 3.831 & 126 & $n / d$ & $\mathrm{n} / \mathrm{d}$ & $n / d$ & $n / d$ \\
\hline \multirow{2}{*}{2005} & ( & 19.767 & 15.432 & 27.289 & 15.07 & 18.658 & 2.382 & 50.467 & 32.708 & 0.683 & 519 & 45.932 & 40.154 & $n / d$ & $n / d$ & $\mathrm{n} / \mathrm{d}$ & $\mathrm{n} / \mathrm{d}$ \\
\hline & Pomeranian & 2.473 & 2.571 & 15.77 & 12.403 & 23.77 & 24.626 & 51.379 & 25.598 & 0.364 & 0.201 & 26.667 & 18.859 & $n / d$ & $n / d$ & $n / d$ & $\mathrm{n} / \mathrm{d}$ \\
\hline \multirow{2}{*}{2004} & sllestan & 31.349 & 24.51 & 24.803 & 14.518 & 17.274 & 8.218 & 43.96 & 30.924 & 0.76 & 0.567 & 39.413 & 36.524 & 0.093 & 0.099 & $n / d$ & $\mathrm{n} / \mathrm{d}$ \\
\hline & Pomeranian & 5.088 & 5.603 & 14.71 & 13.852 & 20.215 & 20.501 & 53.206 & 23.52 & 0.375 & 0.268 & 26.542 & 23.06 & $\mathrm{n} / \mathrm{d}$ & $\mathrm{n} / \mathrm{d}$ & $\mathrm{n} / \mathrm{d}$ & $\mathrm{n} / \mathrm{d}$ \\
\hline \multirow{2}{*}{$\begin{array}{l}\text { Mean } \\
\text { 2004-2013 }\end{array}$} & Silesian & 16.467 & 6.505 & 25.132 & 2.660 & 36.158 & 15.753 & 46.856 & 2.573 & 0.639 & 0.093 & 43.969 & 5.145 & 0.047 & 0.022 & 2.798 & 1.310 \\
\hline & Pomeranian & 4.067 & 1.238 & 12.839 & 4.756 & 24.591 & 3.607 & 52.208 & 3.487 & 0.38 & 0.027 & 25.718 & 1.908 & 0.022 & 0.012 & 1.504 & 0.717 \\
\hline \multicolumn{2}{|l|}{ t } & \multicolumn{2}{|c|}{3.8891} & \multicolumn{2}{|c|}{7.1329} & \multicolumn{2}{|c|}{2.2634} & \multicolumn{2}{|c|}{3.9053} & \multicolumn{2}{|c|}{8.4723} & 10.5 & 185 & & & & \\
\hline$p$-value & & $<$ & $05^{*}$ & $<0$ & & $<0$ & & $<0$. & & & & & & & & & \\
\hline
\end{tabular}

Avg. - average; SD - standard deviation; $\mathrm{t}$ - Student's t-test result; ${ }^{*}$ statistically significant; n/d - no data.

of MIH in the 2 voivodeships. The MIH was observed more than twice as often in children in the Silesian voivodeship (13.7\%) than in the Pomeranian (6.4\%). Furthermore, in children from the Silesian voivodeship, MIH was significantly more often diagnosed on PIs than in their counterparts from the Pomeranian voivodeship (4.9\% compared to $3.2 \%)$. The results are presented in Table 3.

\section{Distribution and prevalence of MIH depending on gender, age and year of birth}

The MIH was diagnosed more often in boys than in girls (54.2\% compared to $45.8 \%$ ), but the gender difference was not statistically significant in either of the voivodeships; nor did the genders differ in terms of the presence of lesions on incisors. In the Pomeranian voivodeship, $\mathrm{MIH}$ was diagnosed more often in children aged 6 (14.53\%) than in older children, which was statistically significant. In the Silesian voivodeship, there were no significant differences between the age groups. A comparison of the occurrence of $\mathrm{MIH}$ in children born in different years is shown in Table 4. There was a gradual increase in the incidence of MIH in children born in later years, but none of the differences were statistically significant (Fig. 4).

\section{Discussion}

According to reports from the European Environment Agency (EEA), ${ }^{23}$ air quality in many cities in Poland falls below European Union (EU) pollution standards. The reports also show differences in the intensity of pollution depending on the region of Poland, with higher concentrations of hazardous substances observed in the south of the country, including the Silesian voivodeship. As many as 3 cities in this voivodeship are in the top 10 European cities with the largest number of days per year in which the permissible concentration of 24-hour PM10 was exceeded. The problem of pollution increases significantly during the heating season. Adverse meteorological conditions (low rainfall or wind) in this area are also contributing factors. The components of air pollution analyzed in this study are those commonly used to assess air quality in EU countries. ${ }^{23}$ 
Table 2, cont. Annual average air pollutants for both voivodeships

\begin{tabular}{|c|c|c|c|c|c|c|c|c|c|c|c|c|c|c|c|c|c|}
\hline \multirow[t]{2}{*}{ Year } & \multirow{2}{*}{$\begin{array}{l}\text { Voivode- } \\
\text { ship }\end{array}$} & \multicolumn{2}{|c|}{$\begin{array}{c}\mathrm{Cd}(\mathrm{PM} 10) \\
{\left[\mathrm{ng} / \mathrm{m}^{3}\right]}\end{array}$} & \multicolumn{2}{|c|}{$\begin{array}{c}\mathrm{Ni}(\mathrm{PM} 10) \\
{\left[\mathrm{ng} / \mathrm{m}^{3}\right]}\end{array}$} & \multicolumn{2}{|c|}{$\begin{array}{c}\mathrm{C}_{6} \mathrm{H}_{6} \\
{\left[\mu \mathrm{g} / \mathrm{m}^{3}\right]}\end{array}$} & \multicolumn{2}{|c|}{$\begin{array}{c}\mathrm{BaP}(\mathrm{PM} 10) \\
{\left[\mathrm{ng} / \mathrm{m}^{3}\right]}\end{array}$} & \multicolumn{2}{|c|}{$\begin{array}{c}\mathrm{BaA}(\mathrm{PM} 10) \\
{\left[\mathrm{ng} / \mathrm{m}^{3}\right]}\end{array}$} & \multicolumn{2}{|c|}{$\begin{array}{c}\mathrm{BbF}(\mathrm{PM} 10) \\
{\left[\mathrm{ng} / \mathrm{m}^{3}\right]}\end{array}$} & \multicolumn{2}{|c|}{$\begin{array}{c}\text { BkF (PM10) } \\
{\left[\mathrm{ng} / \mathrm{m}^{3}\right]}\end{array}$} & \multicolumn{2}{|c|}{$\begin{array}{c}\mathrm{BjF}(\mathrm{PM} 10) \\
{\left[\mathrm{ng} / \mathrm{m}^{3}\right]}\end{array}$} \\
\hline & & Avg. & SD & Avg. & SD & Avg. & SD & Avg. & SD & Avg. & SD & Avg. & SD & Avg. & SD & Avg. & SD \\
\hline \multirow{2}{*}{2013} & Silesian & 1.171 & 1.32 & 2.54 & 3.399 & 2.006 & 1.961 & 6.77 & 7.074 & 5.376 & 5.682 & 4.97 & 4.494 & 2.542 & 2.332 & 4.25 & 3.873 \\
\hline & Pomeranian & 0.249 & 0.165 & 2.293 & 2.308 & 0.658 & 0.951 & 2.589 & 3.956 & 2.101 & 3.573 & 2.82 & 3.92 & 1.126 & 1.553 & 0.728 & 1.177 \\
\hline \multirow{2}{*}{2012} & Silesian & 0.976 & 1.319 & 1.619 & 1.276 & 2.444 & 3.287 & 8.314 & 11.692 & 8.911 & 14.527 & 7.748 & 10.643 & 4.136 & 6.065 & 5.224 & 7.422 \\
\hline & Pomeranian & 0.421 & 0.609 & 6.146 & 8.847 & 0.689 & 1.159 & 3.038 & 5.194 & 2.799 & 7.164 & 2.263 & 3.563 & 0.848 & 1.313 & 3.218 & 8.36 \\
\hline \multirow{2}{*}{2011} & Silesian & 1.351 & 1.448 & 1.775 & 1.414 & 2.047 & 3.02 & 8.908 & 11.069 & 7.012 & 7.972 & 7.763 & 7.515 & 3.849 & 3.779 & 4.746 & 4.485 \\
\hline & Pomeranian & 0.45 & 0.523 & 5.429 & 5.581 & 0.782 & 1.175 & 2.75 & 4.999 & 2.45 & 4.94 & 1.929 & 3.3 & 0.801 & 1.606 & 6.513 & 13.764 \\
\hline \multirow{2}{*}{2010} & Silesian & 1.183 & 1.274 & 2.583 & 2.756 & 1.867 & 3.225 & 9.272 & 11.121 & 10.289 & 12.84 & 9.168 & 10.283 & 3.995 & 4.088 & 5.104 & 5.121 \\
\hline & Pomeranian & 0.446 & 0.492 & 4.194 & 4.342 & 0.684 & 1.272 & 4.683 & 6.91 & 8.885 & 14.144 & 3.856 & 5.121 & 2.63 & 3.655 & 13.285 & 18.491 \\
\hline \multirow{2}{*}{2009} & Silesian & 1.246 & 0.882 & 5.436 & 7.108 & 1.894 & 2.547 & 8.685 & 10.812 & 8.024 & 12.003 & 8.476 & 11.466 & 3.775 & 4.383 & 7.545 & 8.954 \\
\hline & Pomeranian & 0.74 & 0.774 & 3.628 & 5.248 & 1.762 & 2.19 & 3.111 & 3.893 & 3.035 & 3.599 & 2.006 & 2.315 & 1.594 & 1,579 & 5.032 & 5.902 \\
\hline \multirow{2}{*}{2008} & Silesian & $n / d$ & $n / d$ & $n / d$ & $n / d$ & 2.31 & 3.141 & $n / d$ & $n / d$ & $n / d$ & $n / d$ & $n / d$ & $n / d$ & $n / d$ & $n / d$ & $n / d$ & $n / d$ \\
\hline & Pomeranian & 0.703 & 0.755 & 3.397 & 5.081 & 1.401 & 1.625 & 2.152 & 3.179 & $n / d$ & $n / d$ & $\mathrm{n} / \mathrm{d}$ & $n / d$ & $n / d$ & $\mathrm{n} / \mathrm{d}$ & $n / d$ & $\mathrm{n} / \mathrm{d}$ \\
\hline \multirow{2}{*}{2007} & Silesian & $n / d$ & $n / d$ & $n / d$ & $n / d$ & 2.918 & 3.838 & $n / d$ & $n / d$ & $n / d$ & $n / d$ & $n / d$ & $n / d$ & $n / d$ & $n / d$ & $n / d$ & $n / d$ \\
\hline & Pomeranian & $n / d$ & $\mathrm{n} / \mathrm{d}$ & $n / d$ & $n / d$ & 2.402 & 1.652 & 0.925 & 1.574 & $n / d$ & $n / d$ & $\mathrm{n} / \mathrm{d}$ & $n / d$ & $n / d$ & $\mathrm{n} / \mathrm{d}$ & $n / d$ & $\mathrm{n} / \mathrm{d}$ \\
\hline \multirow{2}{*}{2006} & Silesian & $n / d$ & $n / d$ & $n / d$ & $n / d$ & 2.679 & 4.951 & $n / d$ & $n / d$ & $n / d$ & $n / d$ & $n / d$ & $n / d$ & $n / d$ & $n / d$ & $n / d$ & $n / d$ \\
\hline & Pomeranian & $n / d$ & $n / d$ & $n / d$ & $n / d$ & $n / d$ & d & $n / d$ & $n / d$ & $n / d$ & $n / d$ & $n / d$ & $n / d$ & $n / d$ & $\mathrm{n} / \mathrm{d}$ & $n / d$ & $\mathrm{n} / \mathrm{d}$ \\
\hline \multirow{2}{*}{2005} & Silesian & $\mathrm{n} / \mathrm{d}$ & $n / d$ & $n / d$ & $n / d$ & 3.572 & 4.004 & $n / d$ & $n$ & $n / d$ & 11 & $n / d$ & n & $n / d$ & $n / d$ & $n / d$ & n \\
\hline & Pomeranian & $\mathrm{n} / \mathrm{d}$ & $\mathrm{n} / \mathrm{d}$ & $n / d$ & $n / d$ & $n / d$ & $n / d$ & $n / d$ & $n / d$ & $n / d$ & $n / d$ & $\mathrm{n} / \mathrm{d}$ & $n / d$ & $n / d$ & $\mathrm{n} / \mathrm{d}$ & $n / d$ & $\mathrm{n} / \mathrm{d}$ \\
\hline \multirow{2}{*}{2004} & Silesian & $n / d$ & $n / d$ & $n / d$ & $n / d$ & $n / d$ & $n / d$ & $n / d$ & $n / d$ & $n / d$ & $n / d$ & $n / d$ & $n / d$ & $n / d$ & $n / d$ & $n / d$ & $n / d$ \\
\hline & Pomeranian & $n / d$ & $\mathrm{n} / \mathrm{d}$ & $n / d$ & $n / d$ & $n / d$ & $n / d$ & $n / d$ & $n / d$ & $\mathrm{n} / \mathrm{d}$ & $n / d$ & $\mathrm{n} / \mathrm{d}$ & $n / d$ & $n / d$ & $\mathrm{n} / \mathrm{d}$ & $n / d$ & $\mathrm{n} / \mathrm{d}$ \\
\hline \multirow{2}{*}{$\begin{array}{l}\text { Mean } \\
\text { 2004-2013 }\end{array}$} & Silesian & 1.185 & 0.137 & 2.791 & 1.542 & 2.373 & 0.587 & 8.390 & 0.970 & 7.922 & 1.864 & 7.625 & 1.596 & 3.659 & 0.640 & 5.373 & 1.271 \\
\hline & Pomeranian & 0.502 & 0.186 & 4.181 & 1.407 & 1.197 & 0.683 & 2.750 & 1.130 & 3.854 & 2.835 & 2.575 & 0.797 & 1.4 & 0.756 & 5.755 & 4.730 \\
\hline \multicolumn{2}{|l|}{$\mathrm{t}$} & \multicolumn{2}{|c|}{6.7955} & \multicolumn{2}{|c|}{1.5637} & \multicolumn{2}{|c|}{3.7051} & \multicolumn{2}{|c|}{9.0107} & \multicolumn{2}{|c|}{2.6814} & & 307 & 5.0 & 995 & 0.17 & 741 \\
\hline$p$-value & & $<0$. & $05^{*}$ & $>0$ & .05 & $<0.0$ & & $<0$. & $.05^{*}$ & $<0$ & $05^{*}$ & & $.05^{*}$ & $<0$. & $05^{*}$ & $>0$ & .05 \\
\hline
\end{tabular}

Avg. - average; SD - standard deviation; $\mathrm{t}$ - Student's t-test result; * statistically significant; $\mathrm{n} / \mathrm{d}$ - no data.

Table 3. Occurrence of MIH in Pomeranian and Silesian voivodeships

\begin{tabular}{|c|c|c|c|c|c|}
\hline \multirow[b]{2}{*}{ Children } & \multicolumn{2}{|c|}{ Voivodeship } & \multirow{2}{*}{$\begin{array}{l}\text { Total } \\
\text { n (\%) }\end{array}$} & \multirow[b]{2}{*}{$x^{2}$} & \multirow[b]{2}{*}{$p$-value } \\
\hline & $\begin{array}{c}\text { Pomeranian } \\
n(\%)\end{array}$ & $\begin{array}{c}\text { Silesian } \\
\mathrm{n}(\%)\end{array}$ & & & \\
\hline With MIH diagnosis; FPM and PI affected & $88(6.43)$ & $124(13.69)$ & $212(9.32)$ & & \\
\hline Without MIH & $1281(93.57)$ & $782(86.31)$ & $2063(90.68)$ & 33.99 & $<0.001^{*}$ \\
\hline PI affected & $44(3.21)$ & $44(4.86)$ & $88(3.87)$ & & \\
\hline Non-PI affected & $1325(96.79)$ & $862(95.14)$ & $2187(96.13)$ & 3.96 & $0.047^{*}$ \\
\hline Total & 1369 (100) & 906 (100) & 2275 (100) & - & - \\
\hline
\end{tabular}

* statistically significant; FPM - first permanent molars; PI - permanent incisors; MIH - molar incisor hypomineralization.

This study has attempted to assess whether environmental air quality has an impact on the prevalence of $\mathrm{MIH}$ in a given population. It has been shown that in the Silesian voivodeship, where it can be objectively concluded that air quality is inferior, based on measurements of pollution levels and data published by the EEA, the prevalence of $\mathrm{MIH}$ was over twice as high as in the Pomeranian voivodeship. Particular differences pertained to the concentration of $\mathrm{SO}_{2}$, the level of which in the south of Poland was 4 times higher than in the north. Concentrations about twice as high were also observed for $\mathrm{PM} 10 \mathrm{NO}_{2}$, lead and cadmium.

A study assessing the prevalence of $\mathrm{MIH}$ in children from 2 regions of Turkey that significantly differ in terms of industrialization showed no association between MIH prevalence and the levels of polychlorinated dibenzo-p-dioxins (PCDDs) and polychlorinated dibenzofurans (PCDFs) in the environment. The measurements of the concentration of the substances were carried out on the basis of soil samples in a given region. ${ }^{24}$ However, other air-polluting 
Table 4. Occurrence of $\mathrm{MIH}$ depending on the age of the respondents

\begin{tabular}{|c|c|c|c|c|c|c|c|c|c|c|}
\hline \multirow[b]{2}{*}{ Voivodeship } & \multirow[b]{2}{*}{ Children } & \multicolumn{7}{|c|}{ Age [years] } & \multirow[b]{2}{*}{$x^{2}$} & \multirow[b]{2}{*}{$p$-value } \\
\hline & & $\begin{array}{c}6 \\
n(\%)\end{array}$ & $\begin{array}{c}7 \\
\text { n (\%) }\end{array}$ & $\begin{array}{c}8 \\
n(\%)\end{array}$ & $\begin{array}{c}9 \\
n(\%)\end{array}$ & $\begin{array}{c}10 \\
n(\%)\end{array}$ & $\begin{array}{c}11 \\
n(\%)\end{array}$ & $\begin{array}{c}12 \\
n(\%)\end{array}$ & & \\
\hline \multirow{3}{*}{ Pomeranian } & with $\mathrm{MIH}$ & $17(14.53)^{*}$ & $21(7.95)$ & $21(7.17)$ & $12(5.58)$ & $5(2.73)$ & $8(5.33)$ & $3(2.65)$ & \multirow{3}{*}{$21.15^{*}$} & \multirow{3}{*}{$0.002^{*}$} \\
\hline & without MIH & $100(85.47)$ & 243 (92.05) & $272(92.83)$ & $203(94.42)$ & 178 (97.27) & $142(94.67)$ & $110(97.35)$ & & \\
\hline & total & $117(100)$ & $264(100)$ & $293(100)$ & $215(100)$ & $183(100)$ & $150(100)$ & $113(100)$ & & \\
\hline \multirow{3}{*}{ Silesian } & with $\mathrm{MIH}$ & $4(16)$ & 35 (19.13) & $28(15.3)$ & $17(9.77)$ & $22(15.94)$ & $7(8.33)$ & $8(8.70)$ & \multirow{3}{*}{11.77} & \multirow{3}{*}{0.06} \\
\hline & without MIH & $21(84)$ & $148(80.87)$ & $155(84.70)$ & 157 (90.23) & $116(84.06)$ & 77 (91.67) & $84(91.30)$ & & \\
\hline & total & 25 (100) & $183(100)$ & $183(100)$ & $174(100)$ & $138(100)$ & 84 (100) & $92(100)$ & & \\
\hline
\end{tabular}

* statistically significant; MIH - molar incisor hypomineralization.

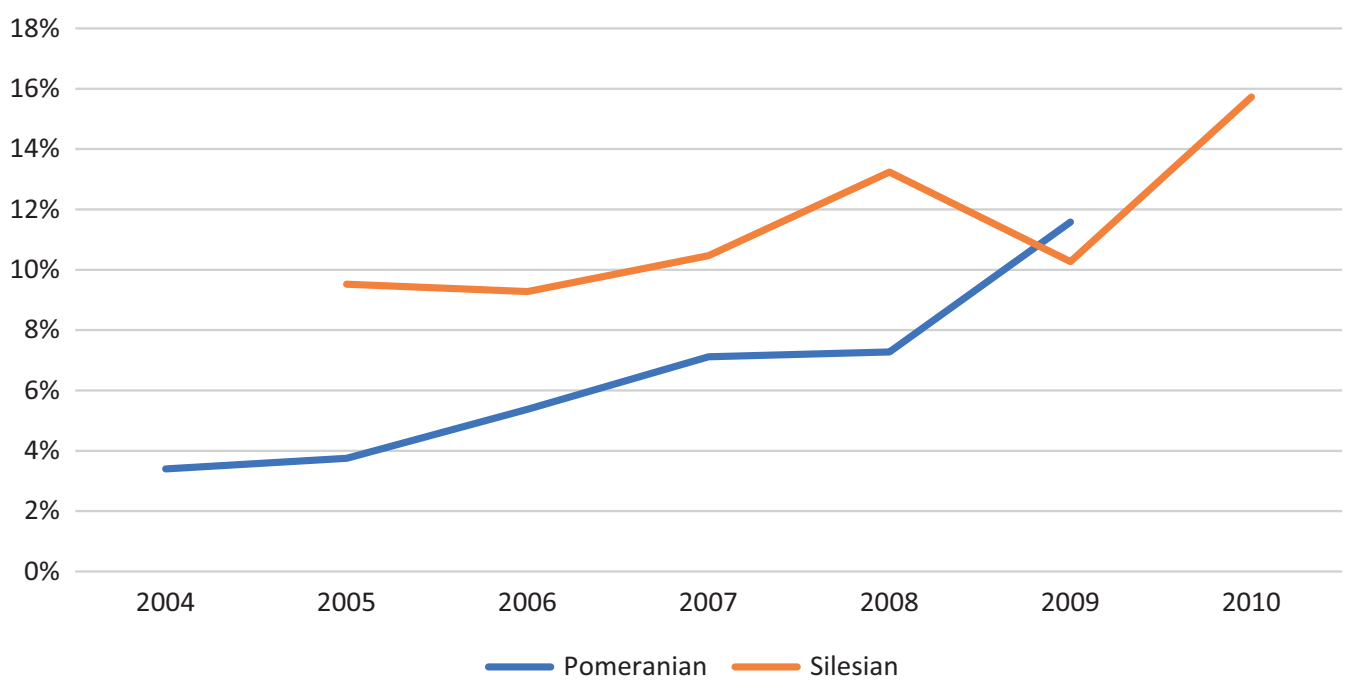

Fig. 4. The prevalence of $\mathrm{MIH}$ in various birth years in the Pomeranian and Silesian voivodeships

Pomeranian $-\left(\chi^{2}(8, n=1369)=12.94 ; n i\right), p=0.095 ;$ Silesian $-\left(\chi^{2}(8, n=906)=10.47 ; n i\right), p=0.202$

substances were not taken into account, and given their negative impact on health, they can undoubtedly have an equally negative effect on tooth development. Apart from the worst effects of pollution described in the literature, such as premature mortality and shortened life expectancy, ${ }^{25}$ air-polluting substances are also responsible for the occurrence of diseases considered in the etiology of $\mathrm{MIH}$, such as otitis media and respiratory diseases, which in children are mainly manifested as irritations, acute infections and asthma attacks. ${ }^{26,27}$ Acute or chronic action of the air polluting substances depends on the time of exposure to a given factor and its concentration and accumulation in the human body. Undoubtedly, the negative impact of pollution on children, in both the prenatal and postnatal periods, is more dangerous and cannot be compared with the effects on adults. The lungs develop throughout childhood and their sensitivity to airborne contaminants at different stages of puberty can vary. ${ }^{28}$ Even if air pollution is not directly responsible for the occurrence of $\mathrm{MIH}$, it can act indirectly, leading to disease and therefore a need to take various medications. Recently, evidence of a relationship between prenatal exposure to air pollution and autism spectrum disorders and cognitive dysfunction has also been identified. ${ }^{29}$
In our study, six-year-old children in the Pomeranian voivodeship displayed a significantly more frequent occurrence of MIH than did children from other age groups. Research in the Pomeranian voivodeship was carried out in 2016 and 2017, so six-year-old children were born in 2010 and 2011. Interestingly, in these years, the highest concentrations of $\mathrm{NO}_{2}$ and $\mathrm{CO}$ in the Pomeranian voivodeship were recorded in the years being analyzed. However, the largest difference and clearly higher concentrations in these years were observed in the case of PAHs, mainly benzo(a)anthracene $\mathrm{BaA}$ (PM10) and benzo(j)fluroantene BjF (PM10). The PAHs are organic compounds consisting of 2 or more fused benzene rings arranged in different configurations. The literature has highlighted their mutagenic and carcinogenic effects. ${ }^{30}$ They are also thought to be detrimental to the nervous system, heart, brain vessels, and respiratory system. ${ }^{31}$ In addition, exposure during the prenatal period is harmful to the developing brain and may thus instigate cognitive dysfunction. ${ }^{32}$ The PAHs arise as a result of incomplete combustion of organic materials (e.g., coal, wood, oil), mainly related to anthropogenic activities but also from natural sources, such as open combustion or volcanic eruptions. Moreover, their presence in the environment leads to their presence in numerous types of food. Processed food 
is considered to be their main source, because cooking processes and techniques such as baking, smoking or drying contribute to their formation. Their presence can be detected in dairy products, nuts, drinks, and meat products (mainly pork), among others. ${ }^{33}$ The PAHs are highly soluble in fats, so they are easily absorbed from the digestive tract and mostly accumulate in adipose tissue ${ }^{30}$ Further research is certainly needed, but based on the results obtained in this study, a link between PAHs exposure during the prenatal period as well as during the first years of life cannot be excluded from the etiology of the occurrence of MIH.

Recently, bisphenol A and its analogs, used worldwide in plastic containers, have been mentioned among the potential etiological factors of enamel disorders. ${ }^{34}$ Researchers who have found evidence of the presence of $\mathrm{MIH}$ in ancient populations are questioning the impact of modern factors such as antibiotics, bisphenol A or dioxin on the occurrence of MIH. These factors were not present in ancient times because they relate to industries that only appeared in the $20^{\text {th }}$ century. Therefore, it has been suggested that MIH etiologies can be found among factors that have been present for centuries. ${ }^{35}$ Still, many components of air pollution have existed since the emergence of human beings and the use of open fire. There is evidence of the presence of, for example, lead, soot and PAHs in ancient times. ${ }^{36}$

The importance of air quality in the etiology of $\mathrm{MIH}$ can additionally be demonstrated by the difference in occurrence in different regions of the country. Problems during pregnancy, childhood diseases and other medical factors occur in children around the world, so MIH etiology should be researched comprehensively in specific local environmental conditions. In line with global trends, another study has found that the number of MIH cases is increasing. ${ }^{9}$

Given the difficulties associated with treatment, MIH is a challenge for both dentists and patients. It is important to establish the etiology of the disorder to discover possible interventions, highlight risk groups and prevent severe complications. ${ }^{5}$

\section{Conclusions}

The results of this study suggest the impact of air pollution on the higher incidence of MIH in a given population. Further research is necessary to determine the specific pollutant. Therefore, although our research points in a specific direction, further research in various regions of different countries is required to confirm these findings.

\section{ORCID iDs}

Natalia Głódkowska (1) https://orcid.org/0000-0002-9876-6703 Katarzyna Emerich (1) https://orcid.org/0000-0003-3175-0931

\section{References}

1. Weerheijm KL, Jälevik B, Alaluusua S. Molar-incisor hypomineralisation. Caries Res. 2001;35(5):390-391. doi:10.1159/000047479

2. Weerheijm KL. Molar incisor hypomineralization $(\mathrm{MIH})$ : Clinical presentation, etiology and management. Dent Uptade. 2004;31(1):9-12. doi:10.12968/denu.2004.31.1.9

3. Leal SC, Oliveira TRM, Ribeiro APD. Do parents and children perceive molar-incisor hypomineralization as oral health problem? Int J Paediatr Dent. 2017;27(5):372-379. doi:10.1111/ipd.12271

4. Silva M, Kilpatrick N, Crombie F, Ghanim A, Manton DJ. What's new in molar incisor hypomineralization? Dent Uptade. 2017;44(2):100-106. doi:10.12968/denu.2017.44.2.100

5. Jälevik B, Klingberg G. Dental treatment, dental fear and behaviour management problems in children with severe enamel hypomineralization of their permanent first molars. Int J Paediatr Dent. 2002;12(1):24-32. doi:10.1046/j.0960-7439.2001.00318.x

6. Albadri S, Zaitoun H, McDonnell ST, Davidson LE. Extraction of first permanent molar teeth: Results from three dental hospitals. Br Dent J. 2007;203(7):E14. doi:10.1038/bdj.2007.679

7. Elfrink ME, Ghanim A, Manton DJ, Weerheijm KL. Standardised studies on molar incisor hypomineralisation $(\mathrm{MIH})$ and hypomineralised second primary molars (HSPM): A need. Eur Arch Paediatr Dent. 2015; 16(3):247-255. doi:10.1007/s40368-015-0179-7

8. Zhao D, Dong B, Yu D, Ren Q, Sun Y. The prevalence of molar incisor hypomineralization: Evidence from 70 studies. Int J Paediatr Dent. 2017;28(2):170-179. doi:10.1111/ipd.12323

9. Schwendicke F, Elhennawy K, Reda S, Bekes K, Manton DJ, Krois J. Global burden of molar incisor hypomineralization. J Dent. 2018;68: 10-18. doi:10.1016/j.jdent.2017.12.002

10. Crombie F, Manton D, Kilpatrick N. Aetiology of molar-incisor hypomineralization: A critical review. Int J Paediatr Dent. 2009;19(2):73-83. doi:10.1111/j.1365-263X.2008.00966.x

11. Arrow P. Risk factors in the occurrence of enamel defects of the first permanent molars among schoolchildren in Western Australia. Community Dent Oral Epidemiol. 2009;37(5):405-415. doi:10.1111/j.16000528.2009.00480.x

12. Garot E, Manton D, Rouas P. Peripartum events and molar-incisor hypomineralisation (MIH) amongst young patients in southwest France. Eur Arch Paediatr Dent 2016;17(4):245-250. doi: 10.1007/s40 368-016-0235-y

13. Ghanim A, Manton D, Bailey D, Mariño R, Morgan M. Risk factors in the occurrence of molar-incisor hypomineralization amongst a group of Iraqi children. Int J Paediatr Dent. 2013;23(3):197-206. doi:10.1111/j.1365-263X.2012.01244.x

14. Serna C, Vicente A, Finke C, Ortiz AJ. Drugs related to the etiology of molar incisor hypomineralization: A systematic review. J Am Dent Assoc. 2016;147(2):120-130. doi:10.1016/j.adaj.2015.08.011

15. Vieira A, Kup E. On the etiology of molar-incisor hypomineralization. Caries Res. 2016;50(2):166-169. doi:10.1159/000445128

16. Jeremias F, Koruyucu M, Küchler EC, et al. Genes expressed in dental enamel development are associated with molar-incisor hypomineralization. Arch Oral Biol 2013;58(10):1434-1442. doi:10.1016/j.archo ralbio.2013.05.005

17. Alaluusua S. Aetiology of molar-incisor hypomineralisation: A systematic review. Eur Arch Paediatr Dent. 2010:11(2):53-58. doi:10.1007/ BF03262713

18. Alaluusua S, Calderara P, Gerthoux PM, et al. Developmental dental aberrations after the dioxin accident in Seveso. Environ Health Perspect. 2004;112(13):1313-1318. doi:10.1289/ehp.6920

19. Fagrell TG, Ludvigsson J, Ullbro C, Lundin SA, Koch G. Aetiology of severe demarcated enamel opacities - an evaluation based on prospective medical and social data from 17,000 children. Swed Dent J. 2011;35(2):57-67.

20. Laisi S, Kiviranta H, Lukinmaa PL, Vartiainen T, Alaluusua S. Molar-incisor-hypomineralisation and dioxins: New findings. Eur Arch Paediatr Dent. 2008;9(4):224-227. doi:10.1007/BF03262639

21. Jan J, Sovcikova E, Kocan A, Wsolova L, Trnovec T. Developmental dental defects in children exposed to PCBs in eastern Slovakia. Chemosphere. 2007;67(9):S350-S354. doi:10.1016/j.chemosphere. 2006.05.148 
22. Weerheijm KL, Duggal M, Mejàre I, et al. Judgement criteria for molar incisor hypomineralisation $(\mathrm{MIH})$ in epidemiologic studies: A summary of the European meeting on MIH held in Athens, 2003. Eur J Paediatr Dent. 2003;4(3):110-113.

23. European Environment Agency (EEA). Air Quality in Europe - 2016 Report. Copenhagen, Denmark: EEA; 2016. doi:10.2800/413142

24. Kuscu OO, Çaglar E, Aslan S, Durmusoglu E, Karademir A, Sandalli N. The prevalence of molar incisor hypomineralization $(\mathrm{MIH})$ in a group of children in a highly polluted urban region and a windfarm-green energy island. Int J Paediatr Dent. 2000;19(3):176-185. doi:10.1111/ j.1365-263X.2008.00945.x

25. Lelieveld J, Evans JS, Fnais M, Giannadaki D, Pozzer A. The contribution of outdoor air pollution sources to premature mortality on a global scale. Nature. 2015;525(7569):367-371. doi:10.1038/nature15371

26. Bowatte G, Tham R, Perret JL, et al. Air pollution and otitis media in children: A systematic review of literature. Int J Environ Res Public Health. 2018;15(2):e257. doi:10.3390/ijerph15020257.

27. Kurt OK, Zhang J, Pinkerton KE. Pulmonary health effects of air pollution. Curr Opin Pulm Med. 2016;22(2):138-144. doi:10.1097/MCP.0000 000000000248

28. Pinkerton $\mathrm{KE}$, Joad JP. Influence of air pollution on respiratory health during perinatal development. Clin Exp Pharmacol Physiol. 2006;33(3): 269-272. doi:10.1111/j.1440-1681.2006.04357.x

29. Oudin A, Frondelius K, Haglund N, et al. Prenatal exposure to air pollution as a potential risk factor for autism and ADHD. Environ Int. 2019; 133(Pt A):105149. doi:10.1016/j.envint.2019.105149
30. Abdel-Shafy HI, Mansour MSM. A review on polycyclic aromatic hydrocarbons: Source, environmental impact, effect on human health and remediation. Egyptian Journal of Petroleum. 2016;25(1):107-123. doi:10.1016/j.ejpe.2015.03.011

31. Li X, Yang $Y, X u X, X u C$, Hong J. Air pollution from polycyclic aromatic hydrocarbons generated by human activities and their health effects in China. Journal of Cleaner Production. 2016;112(2):1360-1367. doi:10.1016/j.jclepro.2015.05.077

32. Jedrychowski WA, Perera FP, Camann D, et al. Prenatal exposure to polycyclic aromatic hydrocarbons and cognitive dysfunction in children. Environ Sci Pollut Res Int. 2015;22(5):3631-3639. doi:10.1007/s11356014-3627-8

33. Singh L, Varshney JG, Agarwal T. Polycyclic aromatic hydrocarbons' formation and occurrence in processed food. Food Chem. 2016;199: 768-781. doi:10.1016/j.foodchem.2015.12.074

34. Jedeon K, De la Dure-Molla M, Brookes SJ, et al. Enamel defects reflect perinatal exposure to bisphenol A. Am J Pathol. 2013;183(1):108-118. doi:10.1016/j.ajpath.2013.04.004

35. Garot E, Couture-Veschambre C, Manton D, Beauval C, Rouas P. Analytical evidence of enamel hypomineralisation on permanent and primary molars amongst past populations. Sci Rep. 2017;7(1):1712. doi:10.1038/s41598-017-01745-w

36. Borsos E, Makra L, Béczi R, Vitányi B, Szentpéteri M. Anthropogenic air pollution in the ancient times. Acta Climatologica et Chorologica. 2003;36-37:5-15. 